\title{
Dried Spent Yeast and Its Hydrolysate as Nitrogen Supplements for Single Batch and Repeated-Batch Ethanol Fermentation from Sweet Sorghum Juice
}

\author{
Sureerat Suwanapong ${ }^{1}$, Naulchan Khongsay ${ }^{1}$, Lakkana Laopaiboon ${ }^{2,3}$, Prasit Jaisil ${ }^{4}$ and \\ Pattana Laopaiboon ${ }^{2,3, *}$
}

1 Graduate School, Khon Kaen University, Khon Kaen 40002, Thailand; E-Mails: ningkitty1985@hotmail.com (S.S.); naul_khong@hotmail.com (N.K.)

2 Department of Biotechnology, Faculty of Technology, Khon Kaen University, Khon Kaen 40002, Thailand; E-Mail: lakcha@kku.ac.th

3 Fermentation Research Center for Value Added Agricultural Products, Khon Kaen University, Khon Kaen 40002, Thailand

4 Department of Plant Science and Agricultural Resources, Faculty of Agriculture, Khon Kaen University, Khon Kaen 40002, Thailand; E-Mail: pjaisil@gmail.com

* Authors to whom correspondence should be addressed; E-Mail: patlao@kku.ac.th; Tel./Fax: +66-4336-2121.

Received: 2 October 2012; in revised form: 18 February 2013 / Accepted: 25 February 2013 / Published: 11 March 2013

Abstract: Dried spent yeast (DSY) and its hydrolysate (DSYH) were used as low-cost nitrogen supplements to improve ethanol production from sweet sorghum juice by Saccharomyces cerevisiae NP01 under very high gravity (VHG) fermentation $\left(280 \mathrm{~g} \cdot \mathrm{L}^{-1}\right.$ of total sugar) conditions. The supplemented DSY and DSYH concentrations were 11, 16 and $21 \mathrm{~g} \cdot \mathrm{L}^{-1}$, corresponding to a yeast extract nitrogen content of 6,9 and $12 \mathrm{~g} \cdot \mathrm{L}^{-1}$, respectively. The initial yeast cell concentration for ethanol fermentation was approximately $5 \times 10^{7}$ cells $\cdot \mathrm{mL}^{-1}$. The fermentation was carried out in single batch mode at $30{ }^{\circ} \mathrm{C}$ in 1-L air-locked bottles with an agitation rate of $100 \mathrm{rpm}$. Ethanol production from the juice with and without yeast extract $\left(9 \mathrm{~g} \cdot \mathrm{L}^{-1}\right)$ was also performed as control treatments. The results showed that DSY at $21 \mathrm{~g} \cdot \mathrm{L}^{-1}$ gave the highest ethanol concentration $\left(P_{E}\right.$, $\left.107 \mathrm{~g} \cdot \mathrm{L}^{-1}\right)$ and yield $\left(Y_{p / s}, 0.47 \mathrm{~g} \cdot \mathrm{g}^{-1}\right)$. The use of DSYH at the same DSY concentration improved ethanol productivity $\left(Q_{p}\right)$, but not $P_{E}$ and $Y_{p / s}$. The ethanol production efficiencies of the juice under DSY and DSYH supplementations were markedly higher than those without nutrient supplementation. However, the $P_{E}$ and $Q_{p}$ values of the juice 
containing $21 \mathrm{~g} \cdot \mathrm{L}^{-1}$ of DSY was approximately $7 \mathrm{~g} \cdot \mathrm{L}^{-1}$ and $0.62 \mathrm{~g} \cdot \mathrm{L}^{-1} \cdot \mathrm{h}^{-1}$ lower than those under the presence of yeast extract $\left(9 \mathrm{~g} \cdot \mathrm{L}^{-1}\right)$, respectively. At the end of the single batch fermentation under the optimum DSY concentration, the sugar consumption was approximately $80 \%$. Therefore in the repeated-batch fermentation, the initial total sugar was reduced to $240 \mathrm{~g} \cdot \mathrm{L}^{-1}$. The results showed that the system could be carried out at least 20 successive batches with the average $P_{E}, Y_{p / s}$ and $Q_{p}$ of $95 \mathrm{~g} \cdot \mathrm{L}^{-1}, 0.46 \mathrm{~g} \cdot \mathrm{g}^{-1}$ and $1.45 \mathrm{~g} \cdot \mathrm{L}^{-1} \cdot \mathrm{h}^{-1}$, respectively.

Keywords: bioethanol; dried spent yeast; low cost nitrogen; repeated-batch fermentation; sweet sorghum

\section{Introduction}

Bio-ethanol is an attractive alternative fuel because it is a renewable bio-based resource and can be produced from several different biomass feedstocks. Corn grain and sugarcane are mainly used in USA and Brazil, respectively, while corn, wheat and cassava are generally used in China [1]. In Thailand, the main raw materials for ethanol production are tapioca starch and sugarcane molasses. It is expected that there will be a limitation of the supply of these raw materials in the near future, because the use of these crops for ethanol production competes with their use as food sources [2]. Non-food feedstocks rich in fermentable carbohydrates are therefore of interest, particularly sweet sorghum, which has the greatest potential for biological transformation into ethanol to be used as bio-fuel $[1,3,4]$. With a growing period of 120-150 days, its stalks contain high levels of fermentable sugar, and it can be planted at nearly all temperatures including tropical climate areas [1,5,6]. It is also one of the most drought resistant agricultural crops because of its capacity to remain dormant during the driest periods [7]. The juice from its stalks also contains many trace elements essential for microbial growth and ethanol production $[4,8]$.

Very high gravity (VHG) fermentation is a process improvement aimed at increasing fermentation rates and ethanol concentrations. The process involves preparation and fermentation of mashes containing sugar in excess of 250 to $270 \mathrm{~g} \cdot \mathrm{L}^{-1}$ [8-10]. It has several advantages for industrial applications such as increase in plant efficiency and capacity, reducing energy, labour and capital costs, as well as increase in ethanol yields per unit of fermentable extract [11]. In addition, the risk of bacterial contamination can be reduced [12]. On the other hand, the drawbacks of this process include increases in osmotic pressure, ethanol stress and nutrient limitation, resulting in decreased yeast viability and slow or stuck fermentations [13].

It was reported that under appropriate environmental and nutritional conditions, Saccharomyces cerevisiae can produce and tolerate high ethanol concentrations [10,12,14]. Our previous study showed that $S$. cerevisiae NP01 isolated from dried starter used for Thai rice wine making was a high-ethanol-producing strain under VHG conditions [15]. In addition, $9 \mathrm{~g} \cdot \mathrm{L}^{-1}$ of yeast extract had protective effects on either growth and fermentation or viability, which stimulated the fermentation rate and ethanol production of $S$. cerevisiae NP01 from sweet sorghum juice $[8,16]$, but this nitrogen source is relatively expensive. 
In the brewery industry, the major by-products are brewer spent grain and brewer's yeast biomass (spent yeast), respectively. Our previous study showed that dried spent yeast (DSY) from Beerthip Brewery, Thailand, contained high nitrogen content and many trace elements $[17,18]$ and therefore, it could be used as a low-cost nitrogen source for ethanol production, instead of yeast extract. In addition, it was reported that the use of treated spent yeast cells subjected to acid hydrolysis significantly improved lactic acid production compared with untreated spent cells [17]. However, there is no report on the use of spent yeast hydrolysate as a nutrient supplement for ethanol production, therefore it is the challenge in this study.

The development of fermentation processes is one of the most important factors for efficient ethanol production [19-22]. In many distilleries, fermentation processes of ethanol production are conducted in single batch or continuous modes $[23,24]$. Repeated-batch or semi-continuous process is the process where a portion of the fermented medium in a fermenter is withdrawn at time intervals, and fresh medium is immediately added into the system. This process has several advantages when compared to the conventional batch fermentation process, including no requirement of new inoculum for each batch, long-term productivity, reduced labor costs and process control and operation $[22,25,26]$. As for the drawbacks of continuous processes, the risk of mutation from outside contamination or internal adaptation is very high due to the long cultivation times. In addition, the process requires a uniform substrate composition; and the constant sterilization of the media can be expensive [27].

The aim of this research was to investigate the effects of DSY and its hydrolysate as low-cost nitrogen supplements on single batch ethanol fermentation from sweet sorghum juice by $S$. cerevisiae NP01 under VHG conditions. Since our previous studies showed that the ethanol concentrations under 3 and $6 \mathrm{~g} \cdot \mathrm{L}^{-1}$ of yeast extract supplementation were lower than that of $9 \mathrm{~g} \cdot \mathrm{L}^{-1}$ [28], ethanol fermentation from the juice with and without yeast extract $\left(9 \mathrm{~g} \cdot \mathrm{L}^{-1}\right)$ supplementation was used as control treatments $[8,28]$. In addition, repeated-batch ethanol fermentation using the "fill and drain" technique under the optimum nutrient supplementation conditions was also investigated.

\section{Experimental Section}

\subsection{Microorganism and Inoculum Preparation}

S. cerevisiae NP01 was grown in $150 \mathrm{~mL}$ of yeast extract malt extract (YM) medium (yeast extract, 3; malt extract, 3; peptone, 5 and glucose, $10 \mathrm{~g} \cdot \mathrm{L}^{-1}$ ) at $200 \mathrm{rpm}, 30^{\circ} \mathrm{C}$ for $24 \mathrm{~h}$. It was then transferred into $360 \mathrm{~mL}$ of the sweet sorghum juice $\left(150 \mathrm{~g} \cdot \mathrm{L}^{-1}\right.$ of total sugar) and incubated under the same conditions for $15 \mathrm{~h}$ [29] before using as the inoculum for ethanol production.

\subsection{Raw Materials}

Sweet sorghum juice (cv. KKU40) extracted from its stalks was obtained from the Department of Plant Science and Agricultural Resources, Faculty of Agriculture, Khon Kaen University, Thailand. To prevent bacterial contamination, the juice containing total soluble solids of $18{ }^{\circ} \mathrm{Bx}$ was concentrated to $75^{\circ} \mathrm{Bx}$ and stored at $4{ }^{\circ} \mathrm{C}$ before use. DSY obtained from Beerthip Brewery (1991) Co., Ltd., Bang Baan, Phra Nakhon Sri Ayutthaya, Thailand was kept at room temperature. Dried spent yeast 
hydrolysate (DSYH) was prepared by hydrolysis of DSY with $3 \mathrm{M} \mathrm{H}_{2} \mathrm{SO}_{4}$ at the initial $\mathrm{pH}$ of 2.0, $121{ }^{\circ} \mathrm{C}$ for $20 \mathrm{~min}$. The ratio of DSY: $\mathrm{H}_{2} \mathrm{SO}_{4}$ was $6: 100(\% w / v)$ [17].

\subsection{Ethanol Production Medium}

For single batch ethanol fermentation, the concentrated juice was diluted with distilled water to obtain $280 \mathrm{~g} \cdot \mathrm{L}^{-1}$ of total sugar concentration and used as an ethanol production (EP) medium. The EP medium was supplemented with DSY at the concentrations of 11,16 and $21 \mathrm{~g} \cdot \mathrm{L}^{-1}$, corresponding to the nitrogen content of yeast extract at 6,9 and $12 \mathrm{~g} \cdot \mathrm{L}^{-1}$, respectively. The medium was transferred into 1-L air-locked bottles with a final working volume of $600 \mathrm{~mL}$ and autoclaved at $110{ }^{\circ} \mathrm{C}$ for 28 min. For the DSYH supplementation, the DSYH at different concentrations (11, 16 and $\left.21 \mathrm{~g} \cdot \mathrm{L}^{-1}\right)$ and the EP medium were autoclaved separately. Then, they were mixed thoroughly to obtain the final total sugar concentration of $280 \mathrm{~g} \cdot \mathrm{L}^{-1}$. The EP medium with and without $9 \mathrm{~g} \cdot \mathrm{L}^{-1}$ of yeast extract $[8,28]$ were also prepared as the control treatments. For repeated-batch ethanol fermentation, the concentrated juice was diluted with distilled water to the desired total sugar concentration and used as the EP medium. The supplement giving the highest ethanol concentration (from the single batch experiments) was added in the EP medium.

\subsection{Fermentation Processes}

\subsubsection{Single Batch Fermentation System}

A factorial design was used for the single batch fermentation with two nitrogen supplements (DSY and DSYH) and three supplement concentrations (11, 16 and $\left.21 \mathrm{~g} \cdot \mathrm{L}^{-1}\right)$. The experiments with and without $9 \mathrm{~g} \cdot \mathrm{L}^{-1}$ of yeast extract were also performed as control treatments. The single batch fermentation was carried out by inoculating $S$. cerevisiae NP01 into sterile EP media in the 1-L air-locked bottles to give an initial cell concentration of $5 \times 10^{7}$ cells $\cdot \mathrm{mL}^{-1}$ [18]. The fermentation was operated at $30{ }^{\circ} \mathrm{C}$ and an agitation rate of $100 \mathrm{rpm}$. Samples were taken at regular time intervals for analysis.

\subsubsection{Repeated-Batch Fermentation System}

In this study, the "fill and drain" technique [26] was used in the repeated-batch system in the 2-L fermenter (Biostat ${ }^{\circledR}$ B, B. Braun Biotech, Melsungen, Germany) with a final working volume of $1 \mathrm{~L}$. The system was first carried out as the single fermentation using the EP medium giving the highest ethanol production efficiency from Section 2.4.1. When the total residual sugar in the broth had dropped slowly as found in the single batch system, the fermented broth (75\% of the working volume) was withdrawn and the same amount of the fresh juice was immediately replaced to initiate the next batch [22]. Twenty successive batches were performed. The samples of each cycle were collected at time intervals for analysis.

\subsection{Analytical Methods}

Proximate chemical composition of DSY and yeast extract, i.e., total carbohydrate, protein, total fat, crude fibre, moisture and ash were determined at the Central Laboratory (Thailand) Co., Ltd., Khon 
Kaen, Thailand, according to AOAC [30,31]. The viable yeast cell numbers, total soluble solids, residual total sugars, ethanol concentration $\left(P_{E}\right)$ and glycerol in the fermentation broth were analyzed, and the ethanol yield $\left(Y_{p / s}, \mathrm{~g} \cdot \mathrm{g}^{-1}\right)$ and volumetric ethanol productivity $\left(Q_{p}, \mathrm{~g} \cdot \mathrm{L}^{-1} \cdot \mathrm{h}^{-1}\right)$ were calculated $[16,29]$. The fermentable nitrogen or assimilable nitrogen for yeast in terms of amino acids and ammonia or free $\alpha$-amino nitrogen (FAN) was estimated by the formol titration method [32].

\subsection{Statistical Analysis}

All the experiments were performed in triplicate, and the results were expressed as mean. Statistical analysis was carried out using SPSS 15.0 for Windows.

\section{Results and Discussion}

\subsection{Proximate Chemical Composition of DSY and Yeast Extract}

The composition of DSY and yeast extract used as the nitrogen supplements are shown in Table 1. After the brewery's spent yeast was dried in a rotary drum drier, the moisture content of DSY was only $2 \%$ higher than that of yeast extract. The total carbohydrate in DSY was about 4.7 folds of that in yeast extract, but the protein content in the former was only $56 \%$ of that in the latter. The total fat content in yeast extract was lower than that in DSY, while crude fibre was rarely detected in either supplement. The ash content in yeast extract was about 2 folds of that in DSY, implying that inorganic compounds in yeast extract were higher than those in DSY. Due to the difference in nitrogen content between DSY and yeast extract, in this study DSY and DSYH concentrations tested were 11,16 and $21 \mathrm{~g} \cdot \mathrm{L}^{-1}$, which corresponded to nitrogen content of yeast extract at 6,9 and $12 \mathrm{~g} \cdot \mathrm{L}^{-1}$, respectively.

Table 1. The composition of DSY (dried spent yeast) and yeast extract.

\begin{tabular}{ccc}
\hline Composition (\%, dry weight) & DSY & Yeast extract \\
\hline Total carbohydrate & 41.92 & 8.98 \\
Protein & 41.75 & 74.50 \\
Total fat & 2.95 & 0.07 \\
Crude fibre & 0.16 & $\mathrm{ND}^{\mathrm{a}}$ \\
Moisture & 7.30 & 5.19 \\
Ash & 6.08 & 11.26 \\
\hline
\end{tabular}

Notes: ${ }^{a}$ not detected; Data in the table show the mean values of the two replications.

\subsection{Effects of DSY for Single Batch Ethanol Fermentation under VHG Conditions}

The profiles of the viable yeast cell numbers, $\mathrm{pH}$, residual total sugar and ethanol concentrations of the EP media containing DSY $\left(11,16\right.$ and $\left.21 \mathrm{~g} \cdot \mathrm{L}^{-1}\right)$ during single batch fermentation are shown in Figure 1. The results showed that $S$. cerevisiae NP01 was well adapted in the sweet sorghum juice with the nitrogen supplements, and neither DSY nor yeast extract promoteed cell growth during the fermentation. Changes of viable yeast cell numbers in the five EP media were similar (Figure 1a). They increased in the first $12 \mathrm{~h}$, without a lag phase being observed, with values of 1.0 to $1.2 \times 10^{8}$ cells $\cdot \mathrm{mL}^{-1}$, and slightly decreased after $40 \mathrm{~h}$ to values of 5.4 to $6.3 \times 10^{7}$ cells $\cdot \mathrm{mL}^{-1}$ at the 
end of the fermentation. The decrease in viable cell number might be due to the depletion of essential nutrients and/or the buildup of toxic by-products (mainly ethanol) in the fermentation broth [33]. The $\mathrm{pH}$ changes in all media during ethanol fermentation were also similar (Figure 1b), with a range of 4.3 to 4.7, which was optimum for yeast growth [34].

Figure 1. Fermentation parameters during single batch ethanol production from sweet sorghum juice with and without DSY (dried spent yeast) or yeast extract supplementation: no supplement $(\bullet), 11(\boldsymbol{\Delta}), 16(\star), 21(\bullet) \mathrm{g} \cdot \mathrm{L}^{-1}$ of DSY and $9 \mathrm{~g} \cdot \mathrm{L}^{-1}$ of yeast extract $(\boldsymbol{\bullet})$. (a) Log viable yeast cells, (b) $\mathrm{pH}$, (c) total sugar and (d) ethanol concentration.
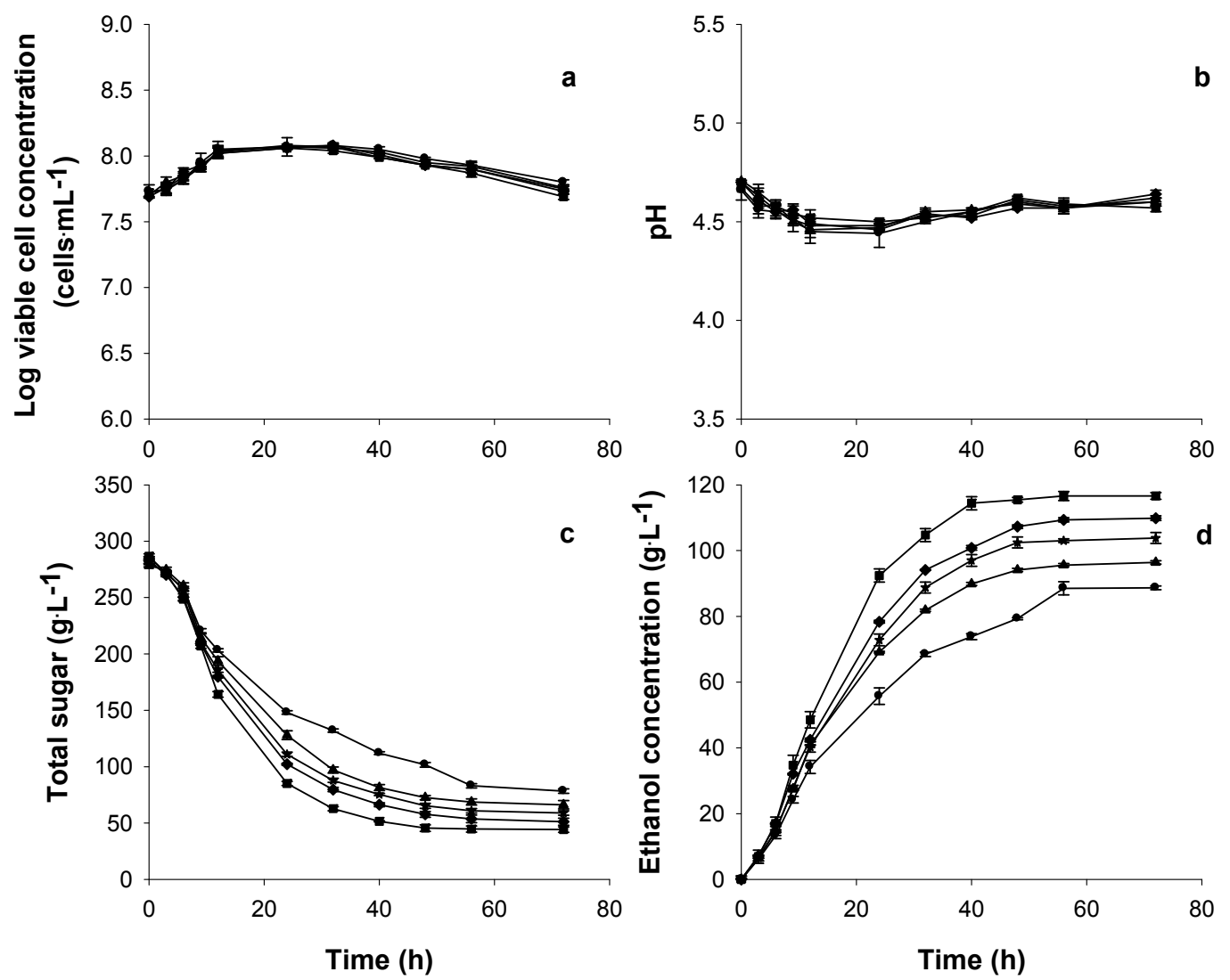

The sugar consumption and ethanol production were the lowest in the EP medium without nutrient supplement (Figures 1c,d), but they were higher with increasing DSY concentrations in the medium. However, the yeast extract supplementation gave the highest sugar consumption and ethanol production. Even though the total nitrogen contents of 11,16 and $21 \mathrm{~g} \cdot \mathrm{L}^{-1}$ of DSY were equal to those of 6,9 and $12 \mathrm{~g} \cdot \mathrm{L}^{-1}$ of yeast extract, respectively, the fermentable nitrogen of the two supplements were markedly different (Table 2). This may explain lower ethanol production under DSY supplementation. Bafrncová et al. [14] suggested that yeast extract had protective effects, either on growth and fermentation or on viability, which stimulated the fermentation rate and ethanol production. From our study, it seemed that yeast extract did not have a protective effect on growth/cell viability under the VHG fermentation conditions (Figure 1a), but it stimulated the fermentation rate and ethanol production (Figure 1d). In addition, Novák and Loubière [35] reported that anabolic precursors, e.g., amino acids, nucleotides, etc., present in yeast extract were essential for ethanol production. 
Table 2. Fermentable nitrogen utilization and main fermentation parameters of single batch ethanol production from sweet sorghum juice containing $280 \mathrm{~g} \cdot \mathrm{L}^{-1}$ of total sugar under various nitrogen supplements.

\begin{tabular}{|c|c|c|c|c|c|c|c|c|}
\hline \multirow{2}{*}{$\begin{array}{c}\text { Nitrogen } \\
\text { supplements }\end{array}$} & \multicolumn{2}{|c|}{$\begin{array}{c}\text { Fermentable } \\
\text { nitrogen }\left(\mathrm{mg} \cdot \mathrm{L}^{-1}\right)\end{array}$} & \multirow[t]{2}{*}{$\begin{array}{l}\text { TSC } \\
(\%)\end{array}$} & \multirow{2}{*}{$\begin{array}{c}P_{E} \\
\left(\mathrm{~g} \cdot \mathrm{L}^{-1}\right)\end{array}$} & \multirow{2}{*}{$\begin{array}{c}Y_{p / s} \\
\left(g^{\prime} \cdot g^{-1}\right)\end{array}$} & \multirow{2}{*}{$\begin{array}{c}Q_{p} \\
\left(\mathrm{~g} \cdot \mathbf{L}^{-1} \mathbf{h}^{-1}\right)\end{array}$} & \multirow[t]{2}{*}{$\begin{array}{c}\text { Glycerol } \\
\left(\mathrm{g} \cdot \mathrm{L}^{-1}\right)\end{array}$} & \multirow[t]{2}{*}{$\begin{array}{c}t \\
\text { (h) }\end{array}$} \\
\hline & Initial & Utilized & & & & & & \\
\hline None & $272^{\mathrm{a}}$ & $157^{\mathrm{a}}$ & $72^{a}$ & $89^{a}$ & $0.44^{\mathrm{a}}$ & $1.58^{\mathrm{a}}$ & $13.5^{\mathrm{f}}$ & 56 \\
\hline $\begin{array}{c}\text { Yeast extract, } \\
9 \mathrm{~g} \cdot \mathrm{L}^{-1}\end{array}$ & $634^{\mathrm{h}}$ & $315^{\mathrm{g}}$ & $82^{d}$ & $114^{\mathrm{g}}$ & $0.49^{\mathrm{c}}$ & $2.86^{\mathrm{g}}$ & $9.4^{\mathrm{a}}$ & 40 \\
\hline DSY, $11 \mathrm{~g} \cdot \mathrm{L}^{-1}$ & $323^{c}$ & $203^{d}$ & $74^{\mathrm{a}, \mathrm{b}}$ & $94^{\mathrm{c}}$ & $0.46^{\mathrm{a}, \mathrm{b}}$ & $1.96^{\mathrm{c}}$ & $12.5^{\mathrm{c}}$ & 48 \\
\hline $\mathrm{DSY}, 16 \mathrm{~g} \cdot \mathrm{L}^{-1}$ & $360^{\mathrm{e}}$ & $221^{\mathrm{e}}$ & $77^{c}$ & $103^{e}$ & $0.46^{\mathrm{a}, \mathrm{b}}$ & $2.13^{d}$ & $13.5^{\mathrm{f}}$ & 48 \\
\hline DSY, $21 \mathrm{~g} \cdot \mathrm{L}^{-1}$ & $387^{\mathrm{g}}$ & $231^{\mathrm{f}}$ & $80^{\mathrm{d}}$ & $107^{\mathrm{f}}$ & $0.47^{\mathrm{b}, \mathrm{c}}$ & $2.24^{\mathrm{e}}$ & $13.3^{\mathrm{e}, \mathrm{f}}$ & 48 \\
\hline DSYH, $11 \mathrm{~g} \cdot \mathrm{L}^{-1}$ & $311^{b}$ & $164^{b}$ & $72^{a}$ & $92^{b}$ & $0.45^{\mathrm{a}, \mathrm{b}}$ & $2.88^{\mathrm{g}}$ & $11.5^{b}$ & 32 \\
\hline DSYH, $16 \mathrm{~g} \cdot \mathrm{L}^{-1}$ & $342^{\mathrm{d}}$ & $176^{\mathrm{c}}$ & $74^{\mathrm{a}, \mathrm{b}}$ & $94^{\mathrm{c}}$ & $0.45^{\mathrm{a}, \mathrm{b}}$ & $2.94^{\mathrm{h}}$ & $12.8^{\mathrm{c}, \mathrm{d}}$ & 32 \\
\hline $\mathrm{DSYH}, 21 \mathrm{~g} \cdot \mathrm{L}^{-1}$ & $363^{f}$ & $178^{\mathrm{c}}$ & $77^{\mathrm{b}, \mathrm{c}}$ & $98^{\mathrm{d}}$ & $0.45^{\mathrm{a}, \mathrm{b}}$ & $2.46^{\mathrm{f}}$ & $13.0^{\mathrm{d}, \mathrm{e}}$ & 40 \\
\hline
\end{tabular}

Notes: DSY $=$ dried spent yeast, DSYH $=$ dried spent yeast hydrolysate, $\mathrm{TSC}=$ total sugar consumption, $P_{E}=$ ethanol concentration, $Y_{p / s}=$ ethanol yield, $Q_{p}=$ ethanol productivity and $t=$ fermentation time. a,b,c,d,e,f,g,h Means followed by the same letter within the same column are not significantly different using Duncan's multiple range test at the level of 0.05 .

\subsection{Effects of DSYH on Single Batch Ethanol Fermentation under VHG Conditions}

The profiles of viable yeast cell numbers and $\mathrm{pH}$ during the ethanol fermentation using DSYH at $11,16,21 \mathrm{~g} \cdot \mathrm{L}^{-1}$ as the nitrogen supplement were similar to those of the DSY supplementation (Figures 1 and 2). The sugar consumption and ethanol production under different DSYH concentrations were similar during the first $24 \mathrm{~h}$, and then increased slightly with increasing DSYH concentrations in the medium. The initial fermentable nitrogen in the EP medium containing 11,16 and $21 \mathrm{~g} \cdot \mathrm{L}^{-1}$ of DSYH was lower than that of DSY for the same concentrations (Table 2), indicating that the acid hydrolysis of DSY destroyed the fermentable nitrogen to some extent.

Comparison of the single batch ethanol fermentation under DSY and DSYH supplementations and the control treatments revealed that the fermentation times under DSYH supplementation were 8 to $16 \mathrm{~h}$ shorter than those under DSY supplementation under the same concentrations, resulting in higher $Q_{p}$ (Table 2). These results were similar to those reported by Gao et al. [17], who studied the effect of acid hydrolysis of spent yeast cells in lactic acid fermentations. They found that the fermentation times of the medium containing untreated spent yeast cells and spent yeast cell hydrolysate were 133 and $113 \mathrm{~h}$, respectively. However, under DSYH conditions, the ethanol concentration was approximately 2 to $9 \mathrm{~g} \cdot \mathrm{L}^{-1}$ lower than that under DSY conditions. This might be due to the fact that the initial fermentable nitrogen concentrations in DSYH (311 to $363 \mathrm{mg} \cdot \mathrm{L}^{-1}$ ) were about 12 to $24 \mathrm{mg} \cdot \mathrm{L}^{-1}$ lower than those of DSY (323 to $387 \mathrm{mg} \cdot \mathrm{L}^{-1}$ ) when compared at the same supplement concentration (Table 2). Bafrncová et al. [14] reported that higher content of free amino nitrogen caused an increase in the final ethanol concentration. In addition, the use of DSY and DSYH did not markedly improve $Y_{p / s}$. The $Y_{p / s}$ value of the control (no supplement) was 0.44 , whereas the $Y_{p / s}$ values of the EP medium supplemented with DSY and DSYH were in the range of 0.45 to 0.47 , indicating that by-products such as glycerol 
were produced under these conditions. When the glycerol concentrations under these conditions were determined, they were in the range of 11.5 to $13.5 \mathrm{~g} \cdot \mathrm{L}^{-1}$ (Table 2). The lowest glycerol concentration $\left(9.4 \mathrm{~g} \cdot \mathrm{L}^{-1}\right)$ was detected in the EP medium supplemented with $9 \mathrm{~g} \cdot \mathrm{L}^{-1}$ of yeast extract, which gave the highest $P_{E}(114), Y_{p / s}(0.49)$ and sugar consumption (82\%).

Figure 2. Fermentation parameters during single batch ethanol production from sweet sorghum juice with and without DSYH (dried spent yeast hydrolysate) or yeast extract supplementation: no supplement $(\bullet), 11(\boldsymbol{\Delta}), 16(\star), 21(\diamond) \mathrm{g} \cdot \mathrm{L}^{-1}$ of DSYH and $9 \mathrm{~g} \cdot \mathrm{L}^{-1}$ of yeast extract (a). (a) Log viable yeast cells, (b) $\mathrm{pH}$, (c) total sugar and (d) ethanol concentration.
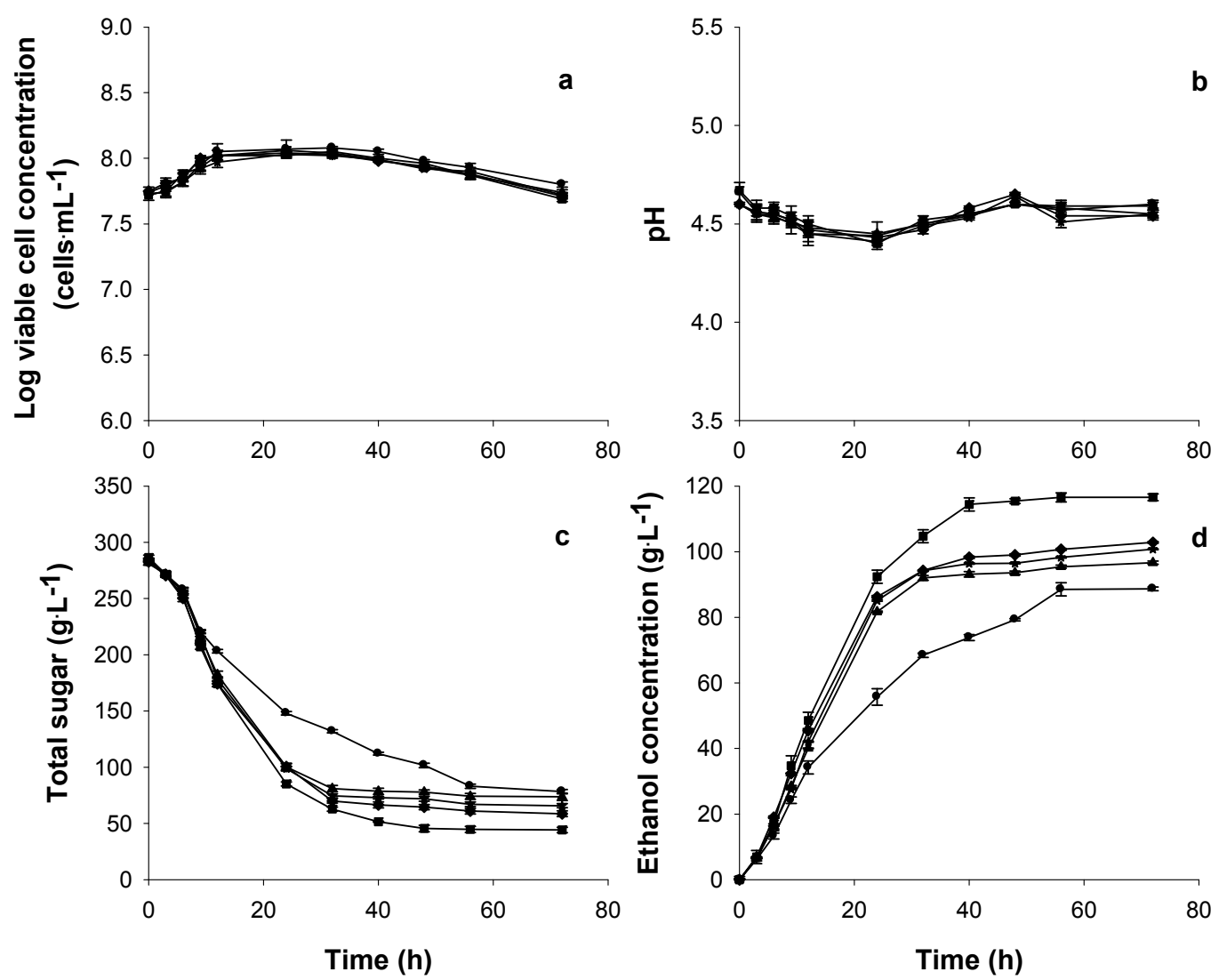

Increasing DSY concentrations in the EP medium could improve the $P_{E}$ and $Q_{p}$ values. Higher DSY concentrations (more than $21 \mathrm{~g} \cdot \mathrm{L}^{-1}$ ) was not tested due to the limited solubility of DSY in the medium. However, under the highest DSY concentration tested $\left(21 \mathrm{~g} \cdot \mathrm{L}^{-1}\right)$, the $P_{E}$ and $Q_{p}$ values were increased 21 and $42 \%$ compared to those of the control treatment (no supplement). The utilized fermentable nitrogen concentrations of DSYH were approximately 39 to $53 \mathrm{mg} \cdot \mathrm{L}^{-1}$ lower than those of DSY at the same concentration (Table 2). It seemed that the amount of fermentable nitrogen utilized was increased with increasing initial fermentable nitrogen. However, the results suggested that fermentable nitrogen was not limited, even in the control medium (no supplement). This implied that the capability of nitrogen utilization by the yeast under VHG condition might also depend on and/or relate to other factors $[10,35]$. 


\subsection{Repeated-Batch Ethanol Fermentation}

According to the results of DSY and DSYH supplementation for single batch ethanol production from the sweet sorghum juice under the VHG conditions, $21 \mathrm{~g} \cdot \mathrm{L}^{-1}$ of DSY gave the highest ethanol concentration and ethanol yield (Table 2). Therefore, DSY at this concentration was selected to be the nutrient supplement for the repeated-batch ethanol fermentation under the VHG conditions. In batch 1, the initial cell concentration and total sugar were $5.1 \times 10^{7}$ cells $\cdot \mathrm{mL}^{-1}$ and $283 \mathrm{~g} \cdot \mathrm{L}^{-1}$, respectively; and the $P_{E}, Y_{p / s}$ and $Q_{p}$ values were $106 \mathrm{~g} \cdot \mathrm{L}^{-1}, 0.47$ and $2.20 \mathrm{~g} \cdot \mathrm{L}^{-1} \cdot \mathrm{h}^{-1}$, respectively at the fermentation time of $48 \mathrm{~h}$ with the sugar remaining of $57 \mathrm{~g} \cdot \mathrm{L}^{-1}$ (Figure 3 ). In batch 2 , the initial total sugar concentration in the fermentation broth was $263 \mathrm{~g} \cdot \mathrm{L}^{-1}$, and the $P_{E}, Y_{p / s}$ and $Q_{p}$ values were $97 \mathrm{~g} \cdot \mathrm{L}^{-1}, 0.36$ and $2.43 \mathrm{~g} \cdot \mathrm{L}^{-1} \cdot \mathrm{h}^{-1}$, respectively at the fermentation time of $40 \mathrm{~h}$ with the sugar remaining of $67 \mathrm{~g} \cdot \mathrm{L}^{-1}$. Longer fermentation times did not cause any increase in the sugar consumption or ethanol production. Due to high total sugar remaining in the fermented broth of batch 1 and 2, the initial total sugar concentration in the EP medium was reduced from 280 to $240 \mathrm{~g} \cdot \mathrm{L}^{-1}$ for the repeated-batch ethanol fermentation.

Figure 3. Fermentation parameters during two cycles of repeated-batch ethanol production from sweet sorghum juice containing $280 \mathrm{~g} \cdot \mathrm{L}^{-1}$ of total sugar and $21 \mathrm{~g} \cdot \mathrm{L}^{-1}$ of DSY (dried spent yeast) in the 2-L fermenter. (a) log viable yeast cells; (b) total sugar; (c) ethanol concentration. The arrows indicate the start time of each batch.
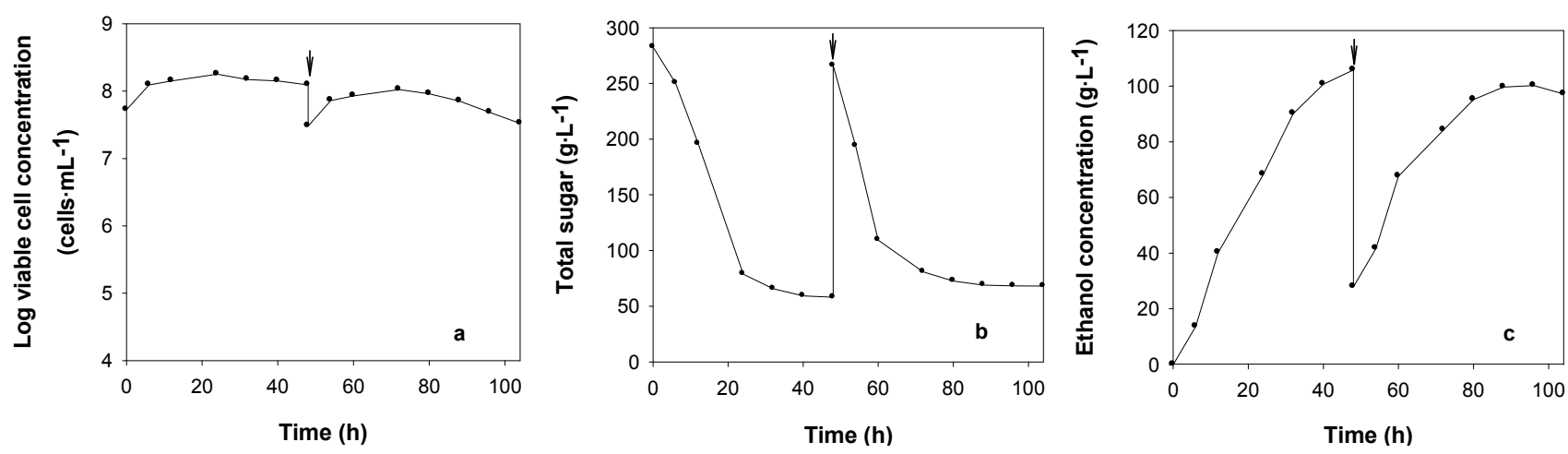

In batch 1 of the repeated-batch ethanol fermentation from the sweet sorghum juice containing $240 \mathrm{~g} \cdot \mathrm{L}^{-1}$ of total sugar and $21 \mathrm{~g} \cdot \mathrm{L}^{-1}$ of DSY, the initial cell concentration, $\mathrm{pH}$ and total sugar were $5.3 \times 10^{7}$ cells $\cdot \mathrm{mL}^{-1}, 4.7$ and $237 \mathrm{~g} \cdot \mathrm{L}^{-1}$, respectively (Figure 4 ). The cell concentration increased to $1.05 \times 10^{8}$ at $24 \mathrm{~h}$ and at the end of the first batch, the total sugar was almost utilized and the viable cell concentration was $5.6 \times 10^{7}$ cells $\cdot \mathrm{mL}^{-1}$. The $P_{E}, Q_{p}$ and $Y_{p / s}$ were $108 \mathrm{~g} \cdot \mathrm{L}^{-1}, 2.25 \mathrm{~g} \cdot \mathrm{L}^{-1} \cdot \mathrm{h}^{-1}$ and $0.50 \mathrm{~g} \cdot \mathrm{g}^{-1}$, respectively at the fermentation time of $48 \mathrm{~h}$ (Figures 4 and 5). The changes of $\mathrm{pH}$ in the repeated-batch fermentation were similar to those of the single batch system. Twenty successive batches were conducted and the fermentation time of each batch was kept constant at $48 \mathrm{~h}$. The viable cell concentrations were continuously decreased in the subsequent batches ranging from $5.6 \times 10^{7}$ to $4.1 \times 10^{5}$ cells $\cdot \mathrm{mL}^{-1}$, while $\mathrm{pH}$ changes of all batches were similar (Figures $4 \mathrm{a}, \mathrm{b}$ ). In batches 2 to 7 , the initial and residual total sugar concentrations in the broth were relatively constant at 165 to $170 \mathrm{~g} \cdot \mathrm{L}^{-1}$ and 21 to $25 \mathrm{~g} \cdot \mathrm{L}^{-1}$, respectively. After batch 7, the initial and residual total sugar concentrations in the broth ranged from 177 to $202 \mathrm{~g} \cdot \mathrm{L}^{-1}$ and 31 to $50 \mathrm{~g} \cdot \mathrm{L}^{-1}$, respectively, whereas the ethanol 
concentrations in batch 2 to 20 ranged from 89 to $103 \mathrm{~g} \cdot \mathrm{L}^{-1}$. The average $Q_{p}$ and $Y_{p / s}$ of batch 2 to 20 were $1.45 \mathrm{~g} \cdot \mathrm{L}^{-1} \cdot \mathrm{h}^{-1}$ and $0.46 \mathrm{~g} \cdot \mathrm{g}^{-1}$ at the fermentation time of $48 \mathrm{~h}$ (each batch), respectively (Figure 5). Lower ethanol concentration and productivity in batches 2 to 20 might be due to lower yeast cell concentrations in the fermentation broth compared with those in the first batch. These results were similar to those of Ariyajarearnwong et al. [21], Chen et al. [36] and Nuangpeng et al. [28]. They demonstrated that the initial cell concentration affected ethanol concentration and productivity in repeated-batch fermentation using free yeast cells. Khongsay et al. [16] reported that supplying aeration at the beginning of each batch in the repeated-batch system increased the yeast cell concentration, resulting in higher ethanol production efficiencies. In addition, to retain high cell concentration in the subsequent batches, a cell recycling system should be applied [37]. However, this technique will increase the production cost.

Figure 4. Fermentation parameters during 20 cycles of repeated-batch ethanol production from sweet sorghum juice containing $240 \mathrm{~g} \cdot \mathrm{L}^{-1}$ of total sugar and $21 \mathrm{~g} \cdot \mathrm{L}^{-1}$ of DSY (dried spent yeast) in the 2-L fermenter. (a) log viable yeast cells; (b) $\mathrm{pH}$; (c) total sugar; (d) ethanol concentration. The arrows indicate the start time of each batch.
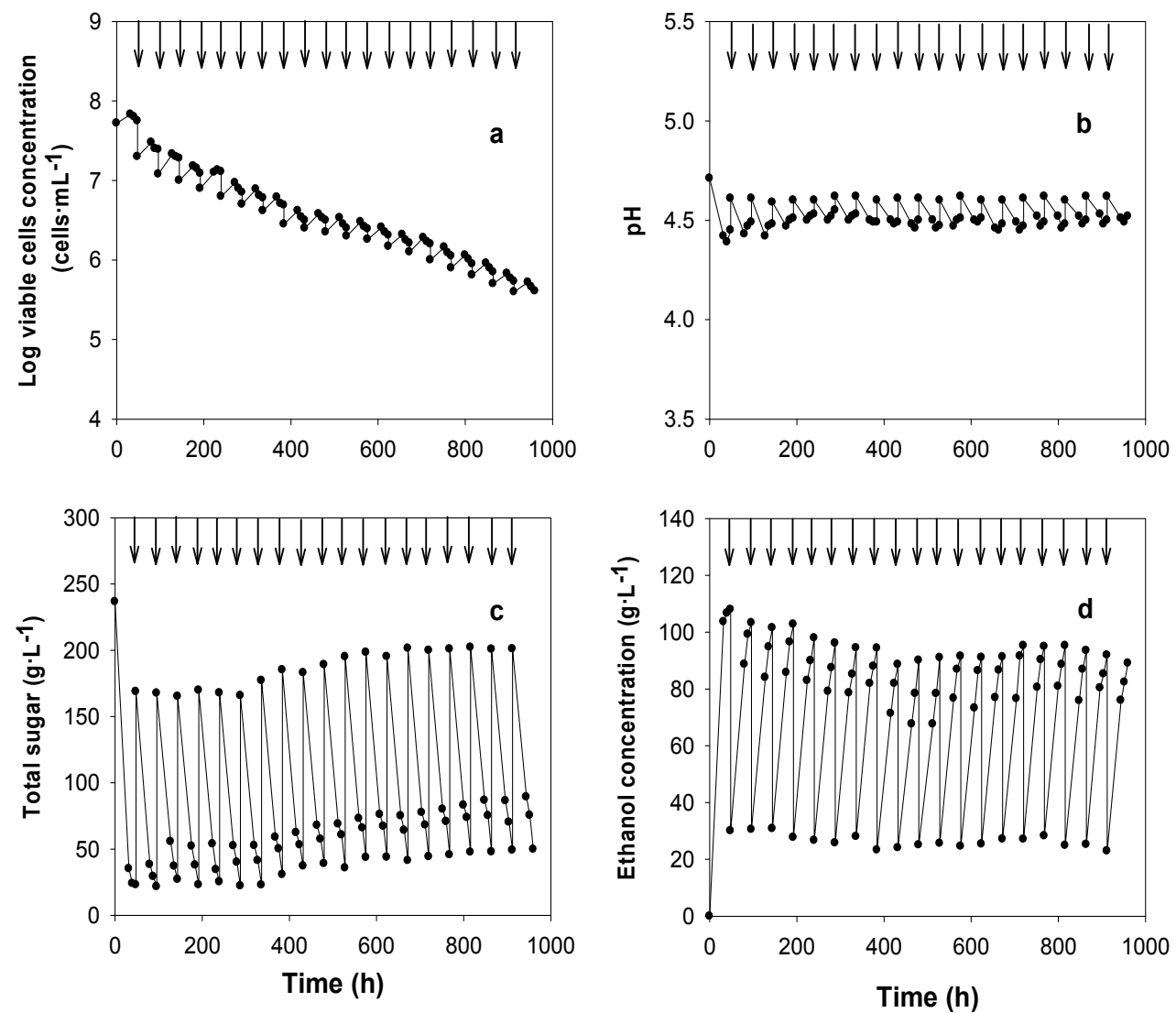

Regarding the ethanol production rate, the total fermentation time of the 20 successive batches was $960 \mathrm{~h}$, and the total amount of ethanol production was $1,448 \mathrm{~g}$ in $15.25 \mathrm{~L}$ of fermentation broth; corresponding to a total rate of ethanol production of $1.5 \mathrm{~g} \cdot \mathrm{h}^{-1}$. This value was comparable to that reported by Ariyajarearnwong et al. $\left(1.8 \mathrm{~g} \cdot \mathrm{h}^{-1}\right)$ [21]. A higher ethanol production rate was reported by Ozmihci and Kargi [38], who studied ethanol production from cheese whey powder solution at a sugar concentration of $125 \mathrm{~g} \cdot \mathrm{L}^{-1}$ using repeated fed-batch fermentation. The ethanol production rate in five 
cycles was $5.3 \mathrm{~g} \cdot \mathrm{h}^{-1}$ with the total fermentation time of $336 \mathrm{~h}$. Lower ethanol production rate in our study compared to that reported by Ozmihci and Kargi [38] might be mainly due to the differences in the initial sugar concentration and the yeast strain. There are several studies which have reported that high substrate concentration in the wort or fermentation broth significantly retarded the ethanol production rate and prolonged fermentation times [15,38,39]. In our study, the initial sugar concentration was about two times higher than that in Ozimihci and Kargi [38]. Therefore, the osmotic stress might have occurred to some extent, resulting in lower ethanol production rate.

Figure 5. Ethanol production efficiencies of repeated-batch fermentation from sweet sorghum juice containing $240 \mathrm{~g} \cdot \mathrm{L}^{-1}$ of total sugar and $21 \mathrm{~g} \cdot \mathrm{L}^{-1}$ of DSY (dried spent yeast) by $S$. cerevisiae NP01. (a) ethanol productivity; (b) ethanol yield.
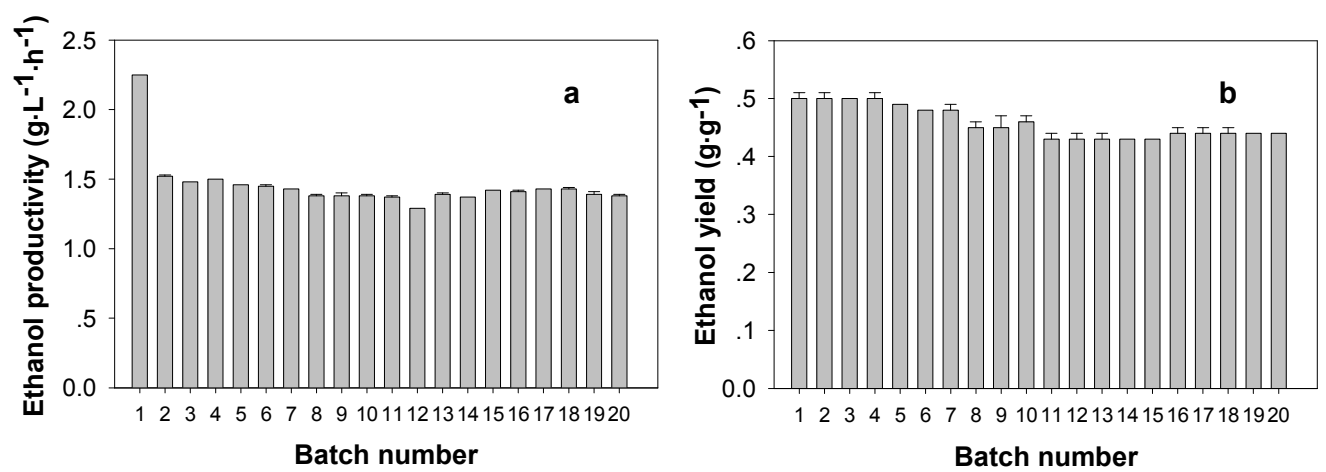

\section{Conclusions}

Nitrogen supplementation was essential for improvement of the ethanol production efficiency from sweet sorghum juice especially under VHG fermentation. The by-product from brewery industry, DSY without pretreatment, could be successfully used as a low-cost nitrogen supplement for single batch and repeated-batch ethanol fermentations. However, the ethanol production efficiencies in terms of $P_{E}$ and $Q_{p}$ from the juice supplemented with DSY $\left(21 \mathrm{~g} \cdot \mathrm{L}^{-1}\right)$ were $7 \mathrm{~g} \cdot \mathrm{L}^{-1}$ and $0.62 \mathrm{~g} \cdot \mathrm{L}^{-1} \cdot \mathrm{h}^{-1}$ lower than those of the juice supplemented with yeast extract $\left(9 \mathrm{~g} \cdot \mathrm{L}^{-1}\right)$, respectively. To obtain higher ethanol production efficiencies, the combination of DSY and yeast extract as nitrogen supplements as well as other key factors is being undertaken.

\section{Acknowledgements}

This research was financially supported by the Higher Education Research Promotion and National Research University Project of Thailand through Biofuels Research Cluster of Khon Kaen University (KKU), Office of the Higher Commission Education and the Fermentation Research Center for Value Added Agricultural Products (FerVAAP), KKU, Thailand. We would like to thank Beerthip Brewery (1991) Co., Ltd., Bang Baan, Phra Nakhon Sri Ayutthaya, Thailand for providing the DSY, Paiboon Danviruthai, Faculty of Technology, KKU for providing the NP01 strain, and Aroonwadee Chanawong, Faculty of Associated Medical Sciences, KKU and Preekamol Klanrit, Faculty of Technology, KKU for their internal reviews of this paper and helpful suggestions. 


\section{References}

1. Li, S.-Z.; Chan-Halbrendt, C. Ethanol production in (the) People's Republic of China: Potential and technologies. Appl. Energy 2009, 86, S162-S169.

2. Pokhrel, C.P.; Yadav, R.K.P.; Ohga, S. Agricultural waste residues as potential sources of bioethanol. Sci. World 2008, 6, 19-23.

3. Göksungur, Y.; Zorlu, N. Production of ethanol from beet molasses by Ca-alginate immobilized yeast cells in a packed-bed bioreactor. Turk. J. Biol. 2001, 25, 265-275.

4. Serna-Saldivar, S.O.; Chuck-Hernandez, C.; Perez-Carrillo, E.; Heredia-Olea, E. Sorghum as a Multifunctional Crop for the Production of Fuel Ethanol: Current Status and Future Trends. In Bioethanol; Pinheiro Lima, M.A., Policastro Natalence, A.P., Eds.; In Tech: London, UK, 2012; Chapter 3, pp. 51-74.

5. Sree, N.K.; Sridhar, M.; Rao, L.V.; Pandey, A. Ethanol production in solid substrate fermentation using thermotolerant yeast. Process Biochem. 1999, 34, 115-119.

6. Wu, X.; Staggenborg, S.; Propheter, J.L.; Rooney, W.L.; Yu, J.; Wang, D. Features of sweet sorghum juice and their performance in ethanol fermentation. Ind. Crop Prod. 2010, 31, 164-170.

7. Wood, J. Integrating Sweet Sorghum and Sugarcane for Bioenergy: Modelling the Potential for Electricity and Ethanol Production in SE Zimbabwe. Ph.D. Thesis, King's College, London, UK, March 2000.

8. Laopaiboon, L.; Nuanpang, S.; Srinophakun, P.; Klanrit, P.; Laopaiboon, P. Ethanol production from sweet sorghum juice using very high gravity technology: Effects of carbon and nitrogen supplementations. Bioresour. Technol. 2009, 100, 4176-4182.

9. Bayrock, D.P.; Ingledew, W.M. Application of multistage continuous fermentation for production of fuel alcohol by very-high-gravity fermentation technology. J. Ind. Microbiol. Biotechnol. 2001, 27, 87-93.

10. Bai, F.W.; Anderson, W.A.; Moo-Young, M. Ethanol fermentation technologies from sugar and starch feedstocks. Biotechnol. Adv. 2008, 1, 89-105.

11. Blieck, L.; Toye, G.; Dumortier, F.; Verstrepen, K.J.; Delvaux, F.R.; Thevelein, J.M.; Dijck, P.V. Isolation and characterization of brewerys yeast variants with improve fermentation performance under high-gravity conditions. Appl. Environ. Microbiol. 2007, 73, 815-824.

12. Thomas, K.C.; Hynes, S.H.; Ingledew, W.M. Practical and theoretical considerations in the production of high concentration of alcohol by fermentation. Process Biochem. 1996, 31, 321-331.

13. Almeida, R.B.; Almeida e Silva, J.B.; Lima, U.A.; Silva, D.P.; Assis, A.N. Evaluation of fermentation parameters during high-gravity beer production. Braz. J. Chem. Eng. 2001, 18, 459-465.

14. Bafrncová, P.; Šmogrovičová, D.; Sláviková, I.; Pátková, J.; Dömény, Z. Improvement of very high gravity ethanol fermentation by media supplementation using Sacchromyces serevisiae. Biotechnol. Lett. 1999, 21, 337-341.

15. Laopaiboon, L.; Nuanpeng, S.; Srinophakun, P.; Klanrit, P.; Laopaiboon, P. Selection of Saccharomyces cerevisiae and investigation of its performance for very high gravity ethanol fermentation. Biotechnology 2008, 7, 493-498. 
16. Khongsay, N.; Laopaiboon, L.; Jaisil, P.; Laopaiboon, P. Optimization of agitation and aeration for very high gravity ethanol fermentation from sweet sorghum juice by Saccharomyces cerevisiae using an orthogonal array design. Energies 2012, 5, 561-576.

17. Gao, M.T.; Hirata, M.; Toorisaka, E.; Hano, E. Study on acid-hydrolysis of spent cells for lactic acid fermentation. Biochem. Eng. J. 2006, 28, 87-91.

18. Sridee, W.; Laopaiboon, L.; Jaisil, P.; Laopaiboon, P. The use of dried spent yeast as a low c-cost nitrogen supplementation from sweet sorghum juice under very high gravity condition. Electron. $J$. Biotechnol. 2011, 14, 1-15.

19. Bai, F.W.; Chen, L.J.; Zhang, Z.; Anderson, W.A.; Moo-Young, M. Continuous ethanol production and evaluation of yeast cell lysis and viability loss under very high gravity medium conditions. J. Biotechnol. 2004, 110, 287-293.

20. Laopaiboon, L.; Thanonkeo, P.; Jaisil, P.; Laopaiboon, P. Ethanol production from sweet sorghum juice in batch and fed-batch fermentations by Saccharomyces cerevisiae. World J. Microbiol. Biotechnol. 2007, 23, 1497-1501.

21. Ariyajarearnwong, P.; Laopaiboon, L.; Jaisil, P.; Laopaiboon, P. Repeated-batch ethanol fermentation from sweet sorghum juice by free cells of Saccharomyces cerevisiae NP 01. Afr. J. Biotechnol. 2011, 10, 13909-13918.

22. Ariyajaroenwong, P.; Laopaiboon, P.; Jaisil, P.; Laopaiboon, L. Repeated-batch ethanol production from sweet sorghum juice by Saccharomyces cerevisiae immobilized on sweet sorghum stalks. Energies 2012, 5, 1215-1228.

23. Alfenore, S.; Cameleyre, X.; Benbadis, L.; Bideaux, C.; Uribelarrea, J.-L.; Goma, G.; Molina-Jouve, C.; Guillouet, S.E. Aeration strategy: A need for very high ethanol performance in Saccharomyces cerevisiae fed-batch process. Appl. Microbiol. Biotechnol. 2004, 63, 537-542.

24. Tang, Y.Q.; An, M.Z.; Zhong, Y.L.; Shigeru, M.; Wu, X.-L; Kida, K. Continuous ethanol fermentation from non-sulfuric acid-washed molasses using traditional stirred tank reactor and the flocculating yeast strain KF7. J. Biosci. Bioeng. 2010, 109, 41-42.

25. Stanbury, P.F.; Whitaker, A.; Hall, S.J. Principles of Fermentation Technology; Pergamon Press: Oxford, UK, 1995; pp. 13-33.

26. Anastassiadis, S.; Rehm, H.J. Citric acid production from glucose by yeast Candida oleophila ATCC 20177 under batch, continuous and repeated batch cultivation. Electron. J. Biotechnol. 2006, 9, 26-39.

27. Roehr, M. The Biotechnology of Ethanol: Classical and Future Applications. Wiley-VCH: Weinheim, Germany, 2001; pp. 139-145.

28. Nuanpeng, S.; Laopaiboon, L.; Srinophakun, P.; Klanrit, P.; Jaisil, P.; Laopaiboon, P. Ethanol production from sweet sorghum juice under very high gravity conditions: Batch, repeated-batch and scale up fermentation. Electron. J. Biotechnol. 2011, 14, 1-12.

29. Deesuth, O.; Laopaiboon, P.; Jaisil, P.; Laopaiboon, L. Optimization of nitrogen and metal ions supplementation for very high gravity bioethanol fermentation from sweet sorghum juice using an orthogonal array design. Energies 2012, 5, 3178-3197.

30. Association of Official Analytical Chemists (AOAC). Compendium of Methods for Food Analysis; AOAC: Gaithersburg, MD, USA, 2003. 
31. Association of Official Analytical Chemists (AOAC). Animal Feed; AOAC: Gaithersburg, MD, USA, 2005.

32. Zoecklien, B.W.; Fugelsang, K.C.; Gump, B.H.; Nury, F.S. Wine Analysis and Production; Chapman \& Hall: New York, NY, USA, 1995.

33. Madigan, M.T.; Martinko, J.M.; Parker, J. Microbial Growth. In Brock Biology of Microorganism, 8th ed; Prentice Hall International: London; UK, 1997; pp. 149-177.

34. Halasz, A.; Lasztity, R. Use of Yeast Biomass in Food Production; CRC Press: Boston, FL, USA, 1991.

35. Novák, L.; Loubiére, P. The metabolic network of Lactococcus lactis: Distriction of 14C-labeled substrates between catabolic and anabolic pathways. J. Bacteriol. 2000, 182, 1136-1143.

36. Chen, J.P.; Wu, K.W.; Fukuda, H. Bioethanol production from uncooked raw starch by immobilized surface-engineered yeast cells. Appl. Biochem. Biotechnol. 2008, 145, 59-67.

37. Choi, G.W.; Kang, H.W.; Moon, S.K. Repeated-batch fermentation using flocculent hybrid, Saccharomyces cerevisiae CHFY0321 for efficient production of bioethanol. Appl. Microbiol. Biotechnol. 2009, 84, 261-269.

38. Ozmichi, S.; Kargi, F. Ethanol fermentation of cheese whet powder solution by repeated fed-batch operation. Enzyme. Microb. Technol. 2007, 41, 169-174.

39. D'Amore, T. Improving yeast fermentation performance. J. Inst. Brew. 1992, 98, 375-382.

(C) 2013 by the authors; licensee MDPI, Basel, Switzerland. This article is an open access article distributed under the terms and conditions of the Creative Commons Attribution license (http://creativecommons.org/licenses/by/3.0/). 